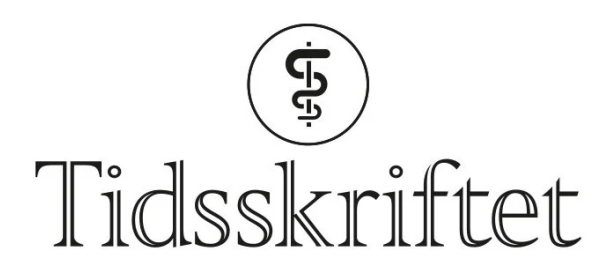

DEN NORSKE LEGEFORENING

\title{
Dislokasjon av kunstig linse
}

\author{
KORT KASUISTIKK
}

OLAV KRISTIANSLUND

olakri@ous-hf.no

Øyeavdelingen

Oslo universitetssykehus

Olav Kristianslund er ph.d., spesialist i øyesykdommer og konstituert overlege.

Forfatteren har fylt ut ICMJE-skjemaet og oppgir ingen interessekonflikter.

\section{MARIUS DALBY}

Øyeavdelingen

Oslo universitetssykehus

og

Institutt for klinisk medisin

Universitetet i Oslo

Marius Dalby er lege i spesialisering i øyesykdommer og ph.d.-stipendiat.

Forfatteren har fylt ut ICMJE-skjemaet og oppgir ingen interessekonflikter.

\section{DROLSUM}

Øyeavdelingen

Oslo universitetssykehus

og

Institutt for klinisk medisin

Universitetet i Oslo

Liv Drolsum er ph.d., spesialist i øyesykdommer, seksjonsoverlege og professor.

Forfatteren har fylt ut ICMJE-skjemaet og oppgir ingen interessekonflikter.

\section{Kataraktkirurgi gir som oftest varig, godt synsresultat. Imidlertid kan den kunstige linsen løsne etter noen år. Her presenteres en kasuistikk der denne komplikasjonen førte til subakutt synstap flere år etter kataraktkirurgi.}

En mann i slutten av 70-årene merket en dag at synet plutselig ble grålig og uklart på det venstre øyet. Dette øyet var kataraktoperert syv år tidligere med standard innsetting av en kunstig intraokulær linse i den eksisterende linsekapselen. Mannen hadde ingen andre kroppslige symptomer og ble henvist til øyelege.

Undersøkelsen viste korrigert Snellen-visus på 1,o (høyre) og o,2 (venstre). Det aktuelle venstre øyet hadde et forhøyet øyetrykk på $33 \mathrm{~mm} \mathrm{Hg}$. Rød refleks var svekket og ujevn, og $\mathrm{i}$ pupilleåpningen kunne man skimte en hvitlig uklarhet. Pupilledilatasjon viste at den kunstige linsen med omsluttende kapsel hadde løsnet og seget nedover slik at øvre 
linseben og en uklar del av kapselen forstyrret synsaksen. I øvre del av komplekset kunne det skimtes en rekke zonulatråder som hadde røket fra festet til corpus ciliare (figur 1). Diagnosen sen kunstig linse-kapsel-dislokasjon ble stilt.

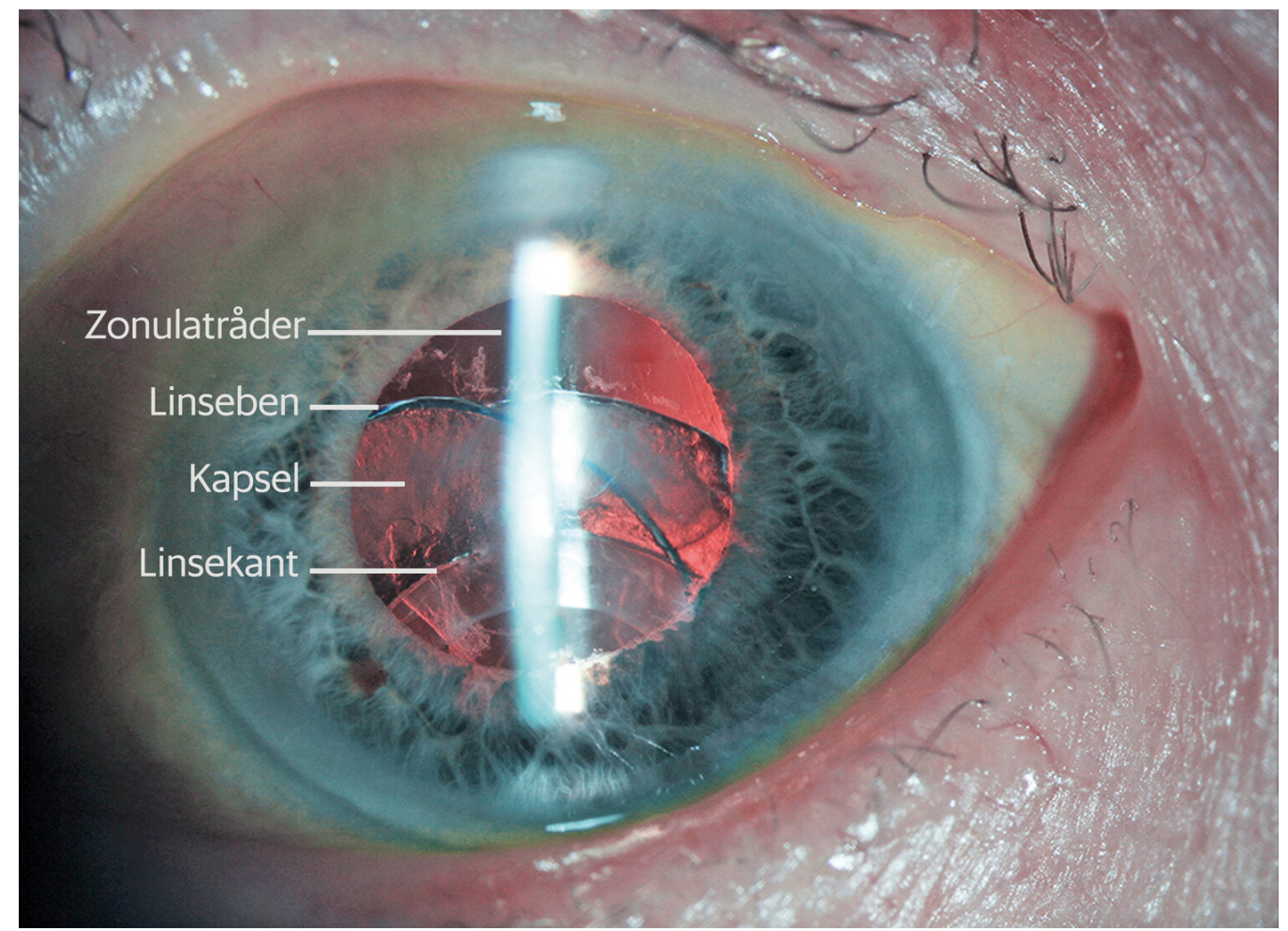

Figur 1 Den kunstige linsen med omsluttende kapsel dislosert nedover.

Pasienten fikk trykksenkende øyedråper, og man fant indikasjon for kirurgi. Han ble inkludert i en forskningsstudie og randomisert til å sy opp den kunstige linsen med omsluttende kapsel til øyeveggen. Operasjonen forløp ukomplisert (figur 2). Visus bedret seg gradvis til 1,25 etter seks uker, og øyetrykket normaliserte seg slik at doseringen av trykksenkende medikamenter kunne reduseres. Undersøkelse av synsnerven viste ingen sikker glaukomskade. Pasienten ble fulgt opp, og det tilkom ingen komplikasjoner.

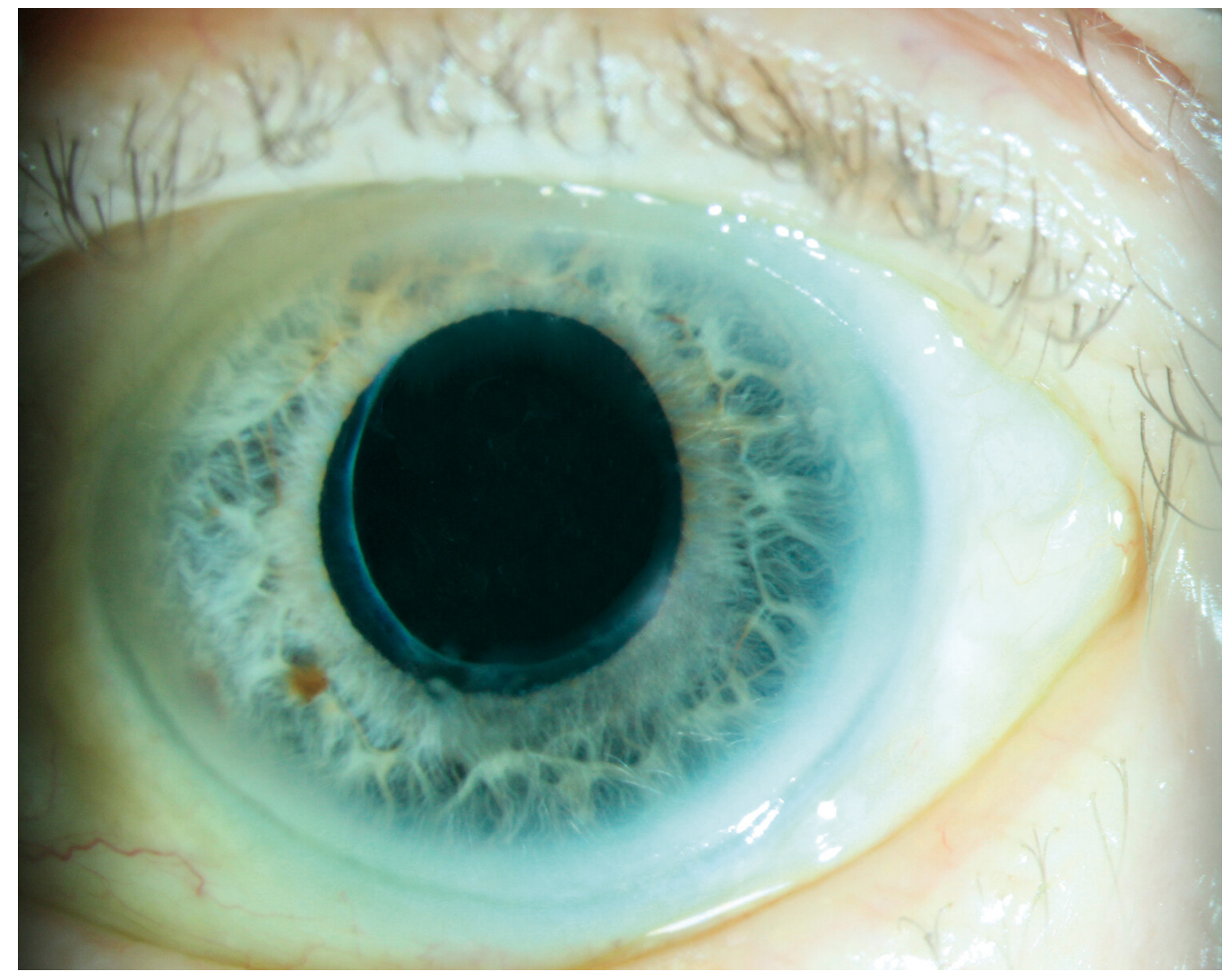


Figur 2 Øyet med sentrert linseoptikk seks uker etter operasjonen.

\section{Diskusjon}

Denne pasienten hadde dislokasjon av den kunstige linsen syv år etter kataraktkirurgi. Denne formen for dislokasjon, som på engelsk kalles late in-the-bag intraocular lens dislocation, ble første gang beskrevet i 1993, og har vært ansett som en sjelden komplikasjon (1). Det er imidlertid rapportert økende forekomst de siste tiårene, med insidens opp mot o,5-1,0 \% av alle kataraktopererte, og dislokasjonen oppstår gjennomsnittlig syv-ti år etter operasjonen $(\underline{2}, 3)$. Selv om denne prosentandelen er lav, dreier det seg om et betydelig antall pasienter. Over halvparten av befolkningen rammes av katarakt før 75 års alder, og det utføres anslagsvis 41 ooo kataraktoperasjoner per år i Norge (4).).

Linsedislokasjon er derfor en problemstilling som også allmennleger og legevaktsleger kan møte. Tilstanden oppstår ofte spontant, men kan forutgås av hodetraume. Det finnes flere predisponerende faktorer, og en av de vanligste er pseudoeksfoliasjonssyndrom, noe vår pasient hadde (3). Dette syndromet ses hovedsakelig hos eldre og er spesielt hyppig i Skandinavia, med rapportert prevalens opp mot $20 \%$ i aldersgruppen over 60 år (5). Syndromet karakteriseres av fibrillære avleiringer i fremre del av øyet, og kan både svekke zonulatrådenes feste av linsekapselen og øke risikoen for glaukom (såkalt kapselglaukom). Flere studier har funnet en klar assosiasjon mellom sen linsedislokasjon og økt øyetrykk, slik som hos vår pasient. Én hypotese er at selve dislokasjonen påvirker trykket (므), mens en annen er at glaukom oppstår i samme tidsrom grunnet pseudoeksfoliasjonssyndrom som felles risikofaktor (7,요). Erfaringen fra litteraturen er at økt øyetrykk hos pasienter med dislosert kunstig linse som oftest krever trykksenkende behandling $(7, \underline{8})$.

Pasienten i denne kasuistikken fikk meget godt syn etter operasjonen. Det har tradisjonelt vært usikker synsprognose ved kirurgi for sen linse-kapsel-dislokasjon, og slike operasjoner har blant en del vært ansett som risikofylte. Det har heller ikke vært klar konsensus om valg av operasjonsmetode. Tidligere publikasjoner har indikert at de mest brukte metodene gir likeverdige resultater, men studiene har vært små og i all hovedsak retrospektive. I en nylig publisert randomisert klinisk studie ble oppsying av det løsnede komplekset sammenliknet med å fjerne det til fordel for ny linse klipset fast til iris. Metodene ga like gode synsresultater, og begge ble vurdert som trygge $(3,9$.$) .$

Dislokasjon av kunstig linse er en viktig tilstand å vite om som differensialdiagnose til blant annet netthinneløsning, karokklusjon eller glasslegemeblødning ved ensidig, smertefritt synstap på et tidligere kataraktoperert øye. Det er få kontraindikasjoner mot kirurgi, og forskning viser god synsprognose ved behandling. Det er ikke behov for å operere akutt, men det er fordelaktig å operere før linsen løsner helt og siger ned i glasslegemet. Vår erfaring er at pasientene bør opereres innen noen uker, avhengig av symptomer og funn. En betydelig andel har forhøyet øyetrykk som også må behandles og følges opp.

Pasienten har gitt samtykke til at artikkelen blir publisert.

Artikkelen er fagfellevurdert.

\footnotetext{
LITTERATUR

1. Davison JA. Capsule contraction syndrome. J Cataract Refract Surg 1993; 19: 582-9. [PubMed] [CrossRef]

2. Mönestam EI. Incidence of dislocation of intraocular lenses and pseudophakodonesis 1o years after cataract surgery. Ophthalmology 2009; 116: 2315-20. [PubMed][CrossRef]

3. Kristianslund $\mathrm{O}$, Råen $\mathrm{M}, \emptyset$ stern $\mathrm{AE}$ et al. Late in-the-bag intraocular lens dislocation: A randomized clinical trial comparing lens repositioning and lens exchange. Ophthalmology 2017; 124: 151-9. [PubMed][CrossRef]
} 
4. Uleberg B, Mathisen S, Shu J et al. Dagkirurgi i Norge 2013-2017. SKDE rapport 2/2018. Senter for klinisk dokumentasjon og evaluering (Helse Nord), 2018:37.

https://helseatlas.no/sites/default/files/dagkirurgi_2013-2017.pdf Lest 13.2.2020.

5. Ringvold A. Epidemiology of the pseudo-exfoliation syndrome. Acta Ophthalmol Scand 1999; 77: 371-5. [PubMed][CrossRef]

6. Jakobsson G, Zetterberg M, Sundelin K et al. Surgical repositioning of intraocular lenses after late dislocation: complications, effect on intraocular pressure, and visual outcomes. J Cataract Refract Surg 2013; 39: 1879-85. [PubMed][CrossRef]

7. Kristianslund O, Råen M, Østern AE et al. Glaucoma and intraocular pressure in patients operated for late in-the-bag intraocular lens dislocation: A randomized clinical trial. Am J Ophthalmol 2017; 176: 219-27. [PubMed][CrossRef]

8. Leung VC, Singh H, Ahmed II. Inter-eye differences in patients with pseudoexfoliation syndrome presenting with intraocular lens dislocation. Ophthalmology 2015; 122: 480-5. [PubMed][CrossRef]

9. Dalby M, Kristianslund O, Drolsum L. Long-term outcomes after surgery of late in-the-bag intraocular lens dislocation: a randomized clinical trial. Am J Ophthalmol 2019; 207: 184-94. [PubMed][CrossRef]

Publisert: 4. mai 2020. Tidsskr Nor Legeforen. DOI:10.4045/tidsskr.19.0526

Mottatt 19.8.2019, første revisjon innsendt 28.11.2019, godkjent 13.2.2020.

(C) Tidsskrift for Den norske legeforening 2023. Lastet ned fra tidsskriftet.no 26. april 2023. 